\title{
Enhanced Enrichment Characteristics and Inhibition Kinetics Characteristics of the Anammox Granular Sludge
}

\author{
Z.Z. Wang*, Y. Ji*, H. Zhang*, L.N. Yan**†, D. Zhao* and P. Gao* \\ *College of Energy and Environmental Engineering, Hebei University of Engineering, Handan 056038, China \\ **College of Environmental and Energy Engineering, Beijing University of Technology, Beijing, 100124, China \\ †Corresponding author: L.N. Yan; w-Z-Z@163.com
}

Nat. Env. \& Poll. Tech.

Website: www.neptjournal.com

Received: 02-09-2019

Revised: $05-10-2019$

Accepted: 07-11-2019

Key Words:

Anammox granular sludge Hydraulic retention time Nitrogen removal performance Inhibition kinetics

\begin{abstract}
The anammox granular sludge was enriched by shortening the hydraulic retention time (HRT) (from 27 $\mathrm{h}$ to $6.67 \mathrm{~h}$ ) in the UASB reactor, which was fed with ammonium chloride and nitrite as the substrates, and the effect of different HRTs on the nitrogen removal performance of anammox granule sludge was studied. After $159 \mathrm{~d}$ of operation, the total nitrogen loading rate $\left(N L R_{T N}\right)$ reached $1.72 \mathrm{Kg} /\left(\mathrm{m}^{3} \cdot \mathrm{d}\right)$, the total nitrogen removal rate $\left(\mathrm{NRR}_{\mathrm{TN}}\right)$ reached $1.33 \mathrm{Kg} /\left(\mathrm{m}^{3} \cdot \mathrm{d}\right)$, and the removal efficiencies of $\mathrm{NH}_{4}^{+} \mathrm{N}$ $\left(\mathrm{NRE}_{\mathrm{NH}+4-\mathrm{N}}\right)$ and $\mathrm{NO}_{2}^{-}-\mathrm{N}\left(\mathrm{NRE}_{\mathrm{NO} 2-\mathrm{N}}\right)$ were over $95 \%$. The ratio of $\Delta \mathrm{NO}_{2}^{-}-\mathrm{N} / \Delta \mathrm{NH}_{4}^{+}-\mathrm{N}$ was 1.31 and $\Delta \mathrm{NO}^{-}$ ${ }_{3}-\mathrm{N} / \Delta \mathrm{NH}_{4}^{+}-\mathrm{N}$ was 0.24 , which complied with the chemical reaction stoichiometry of anammox. The colour of anammox granular sludge changed from light red to deep red; the percentage of granular sludge larger than $1.5 \mathrm{~mm}$ was the highest, which proportionately accounted for $62.32 \%$; and the surface of the granular sludge was found, via Fourier transform infrared spectroscopy (FTIR), to contain abundant functional groups. The inhibitory effect of substrates $\left(\mathrm{NH}_{4}^{+}-\mathrm{N}\right.$ and $\left.\mathrm{NO}_{2}^{-}-\mathrm{N}\right)$ on anammox was studied via an inhibition kinetics batch test using anammox granular sludge (Day 159) in the UASB reactor, and the test results were fitted in the Haldane inhibition model with correlation coefficients $\left(R^{2}\right)$ of 0.9912 and 0.9949 .
\end{abstract}

\section{INTRODUCTION}

The development of petrochemical, food and pharmaceutical industries, as well as the improvement of people's living standards, has sharply driven up the nitrogen content in urban sewage, industrial sewage, and landfill leachate, which has caused the severe nitrogen pollution problem in China's bodies of water. Anammox is a novel biological nitrogen removal technology. In the anaerobic condition, $\mathrm{NO}_{2}^{-}-\mathrm{N}$ is used as an electron acceptor, $\mathrm{NH}_{4}^{+}-\mathrm{N}$ is used as an electron donor, and the reaction product is $\mathrm{N}_{2}$ (Van de Graaf et al. 1996). The reaction formula is shown as Eq. (1), in which $\mathrm{NH}_{4}^{+}-\mathrm{N}: \mathrm{NO}_{2}^{-}: \mathrm{NO}_{3}^{-}$is $1: 1.32: 0.26$. When compared with the traditional biological nitrogen removal technology, the anammox process has the advantages of low energy consumption, high efficiency, no addition of organic carbon sources, and low operating costs (Mulder et al. 1995).

$\mathrm{NH}_{4}^{+}+1.32 \mathrm{NO}_{2}^{-}+0.066 \mathrm{HCO}_{3}^{-}+0.13 \mathrm{H}^{+} \rightarrow 1.02 \mathrm{~N}_{2}+$ $0.26 \mathrm{NO}_{3}^{-}+0.066 \mathrm{CH}_{2} \mathrm{O}_{2.5} \mathrm{~N}_{0.15}+2.03 \mathrm{H}_{2} \mathrm{O}$

Currently, more than 200 full-scale anammox reactors have been applied in wastewater treatment plants around the world, and anammox has broad application prospects as a new biological nitrogen removal technology (Kang et al. 2019, Cao et al. 2017). The granulation of anammox bacteria have excellent sedimentation, can retain high biomass, and can improve the impact load resistance and the exchange of substances and information between anammox bacteria. However, anammox growth is slow, the doubling time is 11 d (Strous et al. 1998), and anammox bacteria are extremely sensitive to environmental conditions, including the environmental temperature $\left(30-40^{\circ} \mathrm{C}\right), \mathrm{pH}(7.5-8.0)$, and loading (Tang et al. 2017). Investigating how anammox granular sludge can be enriched has become a research hotspot (Lin \& Wang 2017).

Although ammonia and nitrite were used as substrates for anammox bacteria, more than a certain concentration will inhibit the growth of anammox bacteria. Chen et al. (2011) used EGSB as a reactor and anammox granular sludge with the MLVSS of $31.31 \mathrm{~g} / \mathrm{L}$ as inoculated sludge. The Haldane model was used to describe the degradation kinetics of inhibition by the test. When the concentration of ammonia reached $707.9 \mathrm{mg} / \mathrm{L}$ and nitrite reached $768.1 \mathrm{mg} / \mathrm{L}$, their degradation rates were at maximum with ammonia reaching $381.2 \mathrm{mg} / \mathrm{gVSS} \cdot \mathrm{d}$ and nitrite reaching $304.7 \mathrm{mg} / \mathrm{gVSS} \cdot \mathrm{d}$. Therefore, studying the inhibition kinetics of anammox has significance for guiding microbial growing.

Consequently, this paper will combine the continuous flow and sequencing batch test to study (1) the effects of 
HRT on the enrichment characteristics of anammox granular sludge and its nitrogen removal performance; (2) granular sludge morphology and its functional group composition; and (3) the inhibition kinetics of substrate concentration on anammox granular sludge, to provide a theoretical basis and technical support for the practical engineering application of the anammox process.

\section{MATERIALS AND METHODS}

Anammox UASB reactor: Fig. 1 shows the UASB reactor, which was composed of Plexiglass with a diameter of $11 \mathrm{~cm}$ and a height of $110 \mathrm{~cm}$. The reactor's upper part was equipped with a three-phase separator for the separation of sludge, water and gas. The reactor was enwrapped with soft black material for heat preservation and protection from light, a water bath cycle was arranged outside the main reactor, two heating rods were arranged in the water bath's circulation tank for controlling the temperature inside the reactor, and the reactor had external reflux for controlling its rising velocity. Test water and inoculated sludge: In this experiment, a continuous culture was carried out, and the anammox granule sludge was further enriched with anammox flocculating sludge and anaerobic granule sludge, both of which were cultured for 160 days under inorganic environmental conditions as inoculated sludge.

Synthetic wastewater was used in the test. The concentration of ammonia nitrogen and nitrite nitrogen was 1:1.32, the concentration of $\mathrm{KH}_{2} \mathrm{PO}_{4}$ was $27.2 \mathrm{mg} / \mathrm{L}$, the concentration of $\mathrm{CaCl}_{2} \cdot 2 \mathrm{H}_{2} \mathrm{O}$ was $180 \mathrm{mg} / \mathrm{L}$, and the concentration of $\mathrm{MgSO}_{4} \cdot 7 \mathrm{H}_{2} \mathrm{O}$ was $300 \mathrm{mg} / \mathrm{L}$. The concentrations of trace elements I and II were both $1 \mathrm{~mL} / \mathrm{L}$. Trace element I $(\mathrm{g} / \mathrm{L})$ consisted of 5 EDTA and $5 \mathrm{FeSO}_{4}$ and trace element II $(\mathrm{g} / \mathrm{L})$ consisted of $15 \mathrm{EDTA}, 0.43 \mathrm{ZnSO}_{4} \cdot 7 \mathrm{H}_{2} \mathrm{O}, 0.24 \mathrm{CoCl}_{2} \cdot 6 \mathrm{H}_{2} \mathrm{O}$, $0.99 \mathrm{MnCl}_{2} 4 \mathrm{H}_{2} \mathrm{O}, 0.25 \mathrm{CuSO}_{4} \cdot 5 \mathrm{H}_{2} \mathrm{O}, 0.22 \mathrm{NaMoO}_{4} \cdot 2 \mathrm{H}_{2} \mathrm{O}$, $0.19 \mathrm{NiCl}_{2} \cdot 6 \mathrm{H}_{2} \mathrm{O}, 0.21 \mathrm{NaSeO}_{4} \cdot 10 \mathrm{H}_{2} \mathrm{O}$ and $0.014 \mathrm{H}_{3} \mathrm{BO}_{3}$.

Analysis methods and calculation formulas: Measurements were made every other day, and the water samples were filtered through $0.45 \mu \mathrm{m}$ filter paper. Test methods were determined via standard methods (APHA 1998), with $\mathrm{NH}_{4}^{+}-\mathrm{N}$, $\mathrm{NO}_{2}^{-}-\mathrm{N}$, and $\mathrm{NO}_{3}^{-}-\mathrm{N}$ determined by a spectrophotometry determination of Nessler's Reagent, N-(1-naphthyl)-ethylenediamine spectrophotometric determination, and ultraviolet spectrophotometry. DO and $\mathrm{pH}$ were determined by German Multi3630, and MLSS and MLVSS were determined by the gravimetric method.

Fourier infrared spectroscopy analysis method: The dried anammox granular sludge and $\mathrm{KBr}$ were tableted at a dose of 1:100, then analysed by Fourier transform infrared spectroscopy. The collected data were analysed by origin 8.0.

Granular sludge particle size determination method: The particle size distribution of the granular sludge was determined by wet sieving (Laguna et al. 1999) with stainless steel meshes with mesh aperture diameters of 3.0, 2.5, 2.0, 1.5, 1.0 and $0.5 \mathrm{~mm}$. The sludge mixture was taken out of

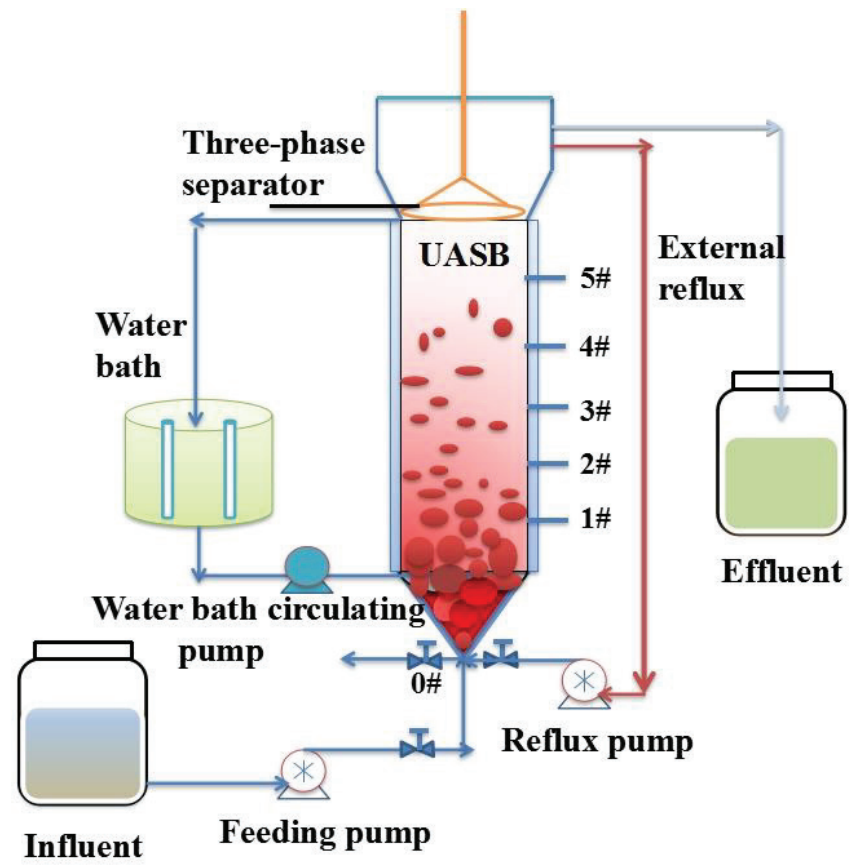

Fig. 1: Schematic diagram of the anammox granular sludge-based UASB reactor. 
the reactor, and the steel sieve was positioned vertically from top to bottom according to pore size. A container was placed under the bottom $0.5 \mathrm{~mm}$ sieve to hold the fine particles, and the sludge sample was slowly poured into the sieve. After screening, the granular sludge of different particle size ranges was collected into different containers, and the MLSS of each screen that intercepted the granular sludge was measured.

Inhibition kinetic sequencing batch test: The anammox granular sludge $(159 \mathrm{~d})$ was taken from the UASB reactor, rinsed three times with clean water to remove the surface matrix, and filtered with filter paper. About $12 \mathrm{~g}$ of wet sludge were weighed with an electronic balance, then placed into a $250 \mathrm{~mL}$ serum bottle, as shown in Fig. 2. The water bath temperature was controlled to about $33^{\circ} \mathrm{C}$, the $\mathrm{pH}$ value was controlled at 7.3-7.6, a $10 \mathrm{~mL}$ syringe was used for sampling, and the solution was fully mixed with a magnetic stirrer. In the single factor inhibition experiment with $\mathrm{NH}_{4}^{+} \mathrm{N}$, other conditions must be controlled. The $\mathrm{NH}_{4}^{+} \mathrm{N}$ gradients were about 70, 100, 200, 320, 500, and $600 \mathrm{mg} / \mathrm{L}$. In the single factor inhibition experiment with $\mathrm{NO}_{2}^{-}-\mathrm{N}$ and other conditions must also be controlled. The $\mathrm{NO}_{2}^{-}-\mathrm{N}$ gradients were about 80, 110, 210, 270, 300, and $400 \mathrm{mg} / \mathrm{L}$. Five $\mathrm{mL}$ was taken with a $10 \mathrm{~mL}$ syringe every $1 \mathrm{~h}$, and the mixture was centrifuged to determine the $\mathrm{NH}_{4}^{+}-\mathrm{N}, \mathrm{NO}_{2}^{-}-\mathrm{N}$ and $\mathrm{NO}_{3}^{-}-\mathrm{N}$ of the supernatant, while the degradation rate of $\mathrm{NH}_{4}^{+} \mathrm{N}$ and $\mathrm{NO}_{2}^{-}-\mathrm{N}$ were calculated.

\section{RESULTS AND DISCUSSION}

Effect of different HRTs on the nitrogen removal performance of anammox granular sludge: The UASB reactor temperature was maintained at $32 \sim 34^{\circ} \mathrm{C}$, the influent $\mathrm{pH}$ value was controlled at 7.3 7.8, and the return flow was kept constant. The test was run under different HRT conditions, and when $\mathrm{NRE}_{\mathrm{NH}+4-\mathrm{N}}$ and $\mathrm{NRE}_{\mathrm{NO}_{2}-\mathrm{N}}$ reached $97 \%$ or more, HRT conditions were adjusted, along with the concentrations of ammonia and nitrite as given in Table 1.

Removal efficiency of $\mathrm{NH}_{4}^{+} \mathrm{N}$ and $\mathrm{NO}_{2}^{-} \mathrm{N}$ by HRTs: The removal efficiency of $\mathrm{NH}_{4}^{+}-\mathrm{N}$ and $\mathrm{NO}_{2}^{-}-\mathrm{N}$ under different $\mathrm{HRT}$ conditions are shown in Fig. 3(a) and (b). In phase I (HRT was $27 \mathrm{~h}$ ), the anammox granular sludge was adapted to the environment because the inoculated sludge HRT was $27 \mathrm{~h}$. After $19 \mathrm{~d}$ of operation, $\mathrm{NRE}_{\mathrm{NH}_{4}^{+} \mathrm{N}}$ was $99.03 \%$, and NRE$\mathrm{NO}_{2}^{-}-\mathrm{N}$ was $99.18 \%$, while the anammox granular sludge was not inhibited. The removal loading of $\mathrm{NH}_{4}^{+}-\mathrm{N}\left(\mathrm{NRR}_{\mathrm{NH}_{4}^{+} \mathrm{N}}\right)$ was $0.17 \mathrm{~kg} / \mathrm{m}^{3} \cdot \mathrm{d}$ and $\mathrm{NO}_{2}^{-}-\mathrm{N}\left(\mathrm{NRR}_{\mathrm{NO}_{2}-\mathrm{N}}\right)$ was $0.22 \mathrm{~kg} / \mathrm{m}^{3} \cdot \mathrm{d}$. In stage II, the other conditions were essentially unchanged. When HRT was shortened to $20.86 \mathrm{~h}$, the substrate loading suddenly increased. The $\mathrm{NRE}_{\mathrm{NH}_{4}^{+} \mathrm{N}}$ decreased to $93.42 \%$ and

Table 1: Operating parameters of anammox granular sludge reactor at different stages.

\begin{tabular}{|c|c|c|c|c|c|c|c|c|}
\hline Stage & Time (d) & HRT (h) & $\begin{array}{l}\text { Velocity } \\
(\mathrm{m} / \mathrm{h})\end{array}$ & Reflux ratio & $\begin{array}{l}\mathrm{NH}_{4}^{+}-\mathrm{N} \text { concentration } \\
(\mathrm{mg} / \mathrm{L})\end{array}$ & $\begin{array}{l}\mathrm{NO}_{2}^{-}-\mathrm{N} \text { concentra- } \\
\text { tion }(\mathrm{mg} / \mathrm{L})\end{array}$ & $\begin{array}{l}\text { NLR } \\
\left(\mathrm{kg} / \mathrm{m}^{3} \cdot \mathrm{d}\right)\end{array}$ & $\begin{array}{l}\mathrm{NRR} \\
\left(\mathrm{kg} / \mathrm{m}^{3} \cdot \mathrm{d}\right)\end{array}$ \\
\hline I & $1 \sim 19$ & 27.00 & 4.78 & 121 & 187.29 & 242.48 & 0.40 & 0.34 \\
\hline II & $20 \sim 47$ & 20.86 & 4.79 & 90 & 198.24 & 253.60 & 0.54 & 0.45 \\
\hline III & $48 \sim 81$ & 15.50 & 4.80 & 70 & 177.96 & 233.70 & 0.70 & 0.55 \\
\hline IV & $82 \sim 119$ & 8.63 & 4.86 & 40 & 175.56 & 234.39 & 1.16 & 0.95 \\
\hline V & $120 \sim 159$ & 6.67 & 4.89 & 30 & 173.19 & 234.17 & 1.72 & 1.33 \\
\hline
\end{tabular}

Temperature probe

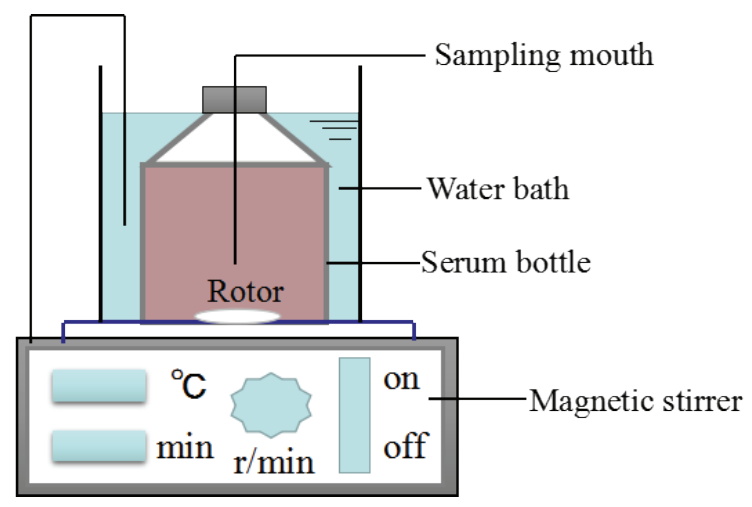

Fig. 2: Schematic diagram of the batching test. 
$\mathrm{NRE}_{\mathrm{NO}_{2}-\mathrm{N}}$ to $95.31 \%$, while $\mathrm{NRR}_{\mathrm{NH}_{4}^{+} \mathrm{N}}$ rose to $0.21 \mathrm{~kg} / \mathrm{m}^{3} \cdot \mathrm{d}$ and $\mathrm{NRR}_{\mathrm{NO}_{-}-\mathrm{N}}$ rose to $0.29 \mathrm{~kg} / \mathrm{m}^{3} \cdot \mathrm{d}$. After $27 \mathrm{~d}, \mathrm{NRE}_{\mathrm{NH}_{4}^{+} \mathrm{N}}$ reached $98.15 \%$ and $\mathrm{NRE}_{\mathrm{NO}_{2}-\mathrm{N}}$ reached $98.72 \%$.

When HRT was shortened to $15.50 \mathrm{~h}$, in Phase III, the $\mathrm{NRE}_{\mathrm{NH}_{4}^{+} \mathrm{N}}$ began to decrease due to the sudden shortening of HRT and fluctuated around $90 \%$. However, the decrease of $\mathrm{NO}_{2}^{-}-\mathrm{N}$ was large, and $\mathrm{NRE}_{\mathrm{NO}_{2}-\mathrm{N}}$ decreased from $98.72 \%$ in the previous phase to $87.74 \%$, indicating that the inhibition of nitrite nitrogen was more obvious. After $33 \mathrm{~d}$ of operation, the activity of anammox bacteria was restored, $\mathrm{NRE}_{\mathrm{NH}_{4}^{+} \mathrm{N}}$ was 97.54\% and $\mathrm{NRE}_{\mathrm{NO}_{2}^{-} \mathrm{N}}$ was $97.37 \%$, and $\mathrm{NRR}_{\mathrm{NH}_{4}^{+} \mathrm{N}}$ reached $0.27 \mathrm{~kg} / \mathrm{m}^{3} \cdot \mathrm{d}$ and $\mathrm{NRR}_{\mathrm{NO}_{2}-\mathrm{N}}$ reached $0.36 \mathrm{~kg} / \mathrm{m}^{3} \cdot \mathrm{d}$. In phase IV (HRT was $8.63 \mathrm{~h}$ ), the anammox granular sludge activity was better, and at the end of phase IV, $\mathrm{NRE}_{\mathrm{NH}_{4}^{+} \mathrm{N}}$ was $98.27 \%$ and $\mathrm{NRE}_{\mathrm{NO}_{2}-\mathrm{N}}$ was $98.68 \%$.

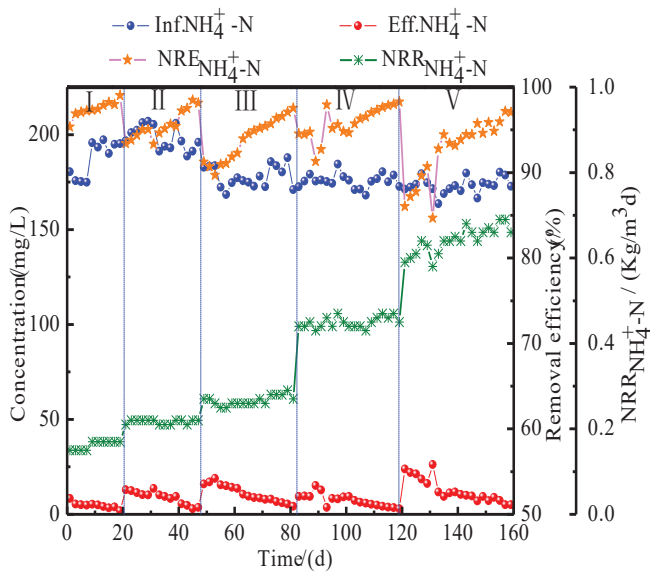

(a)

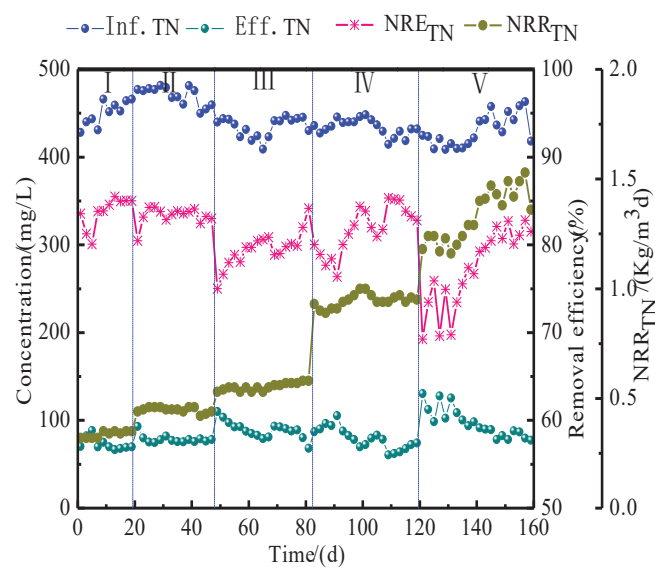

(c)
In phase $\mathrm{V}$, the $\mathrm{HRT}$ was shortened to $6.67 \mathrm{~h}, \mathrm{NRE}_{\mathrm{NH}_{4}^{+} \mathrm{N}}$ was significantly reduced to $86.05 \%$, and $\mathrm{NRE}_{\mathrm{NO}_{2}-\mathrm{N}}$ was decreased to $79.95 \%$. The reasons for analysis are as follows: (1) The shorter the HRT, the higher the loading of the ammonia nitrogen and nitrite nitrogen, and the anammox activity was inhibited, resulting in a decrease of the treatment effect; (2) The HRT was short and part of the ammonia and the nitrite were discharged outside of the reactor without reaction, increasing the effluent concentration, and a decrease of the removal loading of the ammonia and nitrite. After 39 days, $\mathrm{NRE}_{\mathrm{NH}_{4}^{+} \mathrm{N}}$ was $97.05 \%$ and $\mathrm{NRE}_{\mathrm{NO}_{2}-\mathrm{N}}$ was $98.21 \%$, and the anammox activity was further improved.

Removal efficiency of TN by HRT: The removal efficiency of TN $\left(\mathrm{NRE}_{\mathrm{TN}}\right)$ under different HRT conditions is shown in Fig. 3(c) and (d). HRT was $27 \mathrm{~h}$ in phase I. On the first day

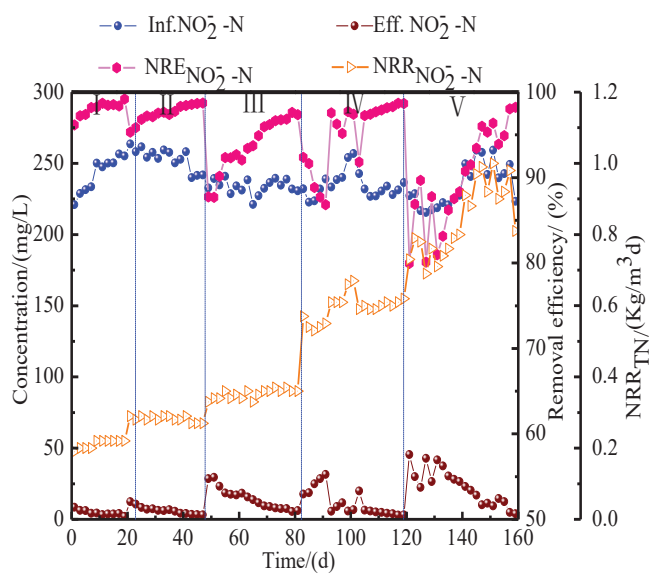

(b)

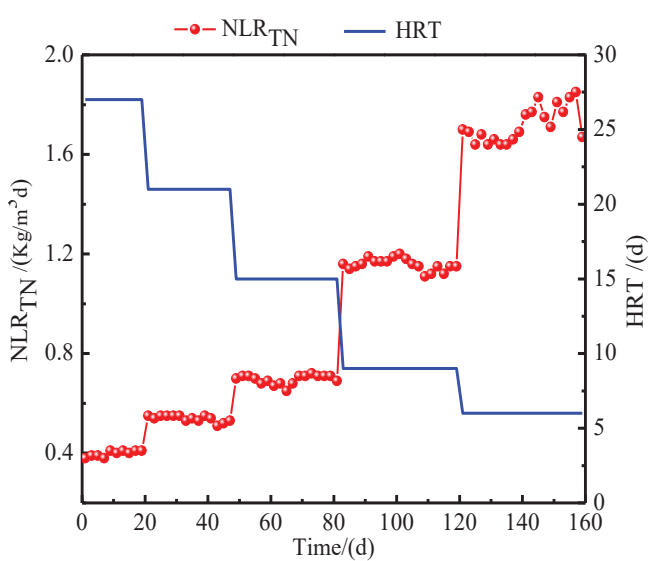

(d)

Fig. 3. Under different HRTs (a) $\mathrm{NH}_{4}^{+}-\mathrm{N}$, (b) $\mathrm{NO}_{2}^{-}-\mathrm{N}$, (c) TN nitrogen removal performance, and (d) the variation of NLR. 
of operation, TN concentration was $428.04 \mathrm{mg} / \mathrm{L}$, total nitrogen output was $70.33 \mathrm{mg} / \mathrm{L}, \mathrm{NRR}_{\mathrm{TN}}$ was $0.32 \mathrm{~kg} / \mathrm{m}^{3} \cdot \mathrm{d}$, and $\mathrm{NRE}_{\mathrm{TN}}$ was $83.57 \%$. After $19 \mathrm{~d}$ of operation, $\mathrm{NRE}_{\mathrm{TN}}$ reached $85.02 \%$, and $\mathrm{NRR}_{\mathrm{TN}}$ was increased to $0.35 \mathrm{~kg} / \mathrm{m}^{3} \cdot \mathrm{d}$. Other conditions remained unchanged. When HRT was shortened to $20.86 \mathrm{~h}$, on the first day of operation $\mathrm{NRE}_{\mathrm{TN}}$ decreased to $83.77 \%$, and $\mathrm{NRE}_{\mathrm{TN}}$ continued to drop to $80.47 \%$ on the second day. The anammox activity was slightly inhibited due to the shortening of HRT, however, after $27 \mathrm{~d}$ of operation, $\mathrm{NRE}_{\mathrm{TN}}$ reached $83.01 \%, \mathrm{NRR}_{\mathrm{TN}}$ reached $0.44 \mathrm{~kg} / \mathrm{m}^{3} \cdot \mathrm{d}$, and $\mathrm{NLR}_{\mathrm{TN}}$ reached $0.53 \mathrm{~kg} / \mathrm{m}^{3} \cdot \mathrm{d}$. The anammox activity was also improved. Then HRT was shortened to $15.50 \mathrm{~h}$, and $\mathrm{NRE}_{\mathrm{TN}}$ was reduced to $75.01 \%$. After $33 \mathrm{~d}, \mathrm{NRE}_{\mathrm{TN}}$ was increased to $84.16 \%, \mathrm{NRR}_{\mathrm{TN}}$ reached $0.58 \mathrm{~kg} / \mathrm{m}^{3} \cdot \mathrm{d}$, and $\mathrm{NLR}_{\mathrm{TN}}$ was 0.69 $\mathrm{kg} / \mathrm{m}^{3} \cdot \mathrm{d}$. In phase IV, HRT was $8.63 \mathrm{~h}$, anammox activity was high, $\mathrm{NRR}_{\mathrm{TN}}$ was reduced by about $2 \%$, and $\mathrm{NRE}_{\mathrm{TN}}$ was maintained at about $80 \%$. When HRT was shortened to $6.67 \mathrm{~h}$, $\mathrm{NRE}_{\mathrm{TN}}$ was decreased by $69.27 \%$, and activity was severely inhibited, resulting in a significant decrease in the removal efficiency. After $39 \mathrm{~d}$, anammox activity was essentially restored, $\mathrm{NRE}_{\mathrm{TN}}$ reached $81.53 \%, \mathrm{NRR}_{\mathrm{TN}}$ was $1.33 \mathrm{~kg} / \mathrm{m}^{3} \cdot \mathrm{d}$ and $\mathrm{NLR}_{\mathrm{TN}}$ was $1.72 \mathrm{~kg} / \mathrm{m}^{3} \cdot \mathrm{d}$. This showed that anammox activity was further improved and the ability to withstand the loading of nitrogen was strengthened. Yu et al. (2014) studied the effect of nitrogen performance on different HRTs, with HRTs of $72 \mathrm{~h}, 48 \mathrm{~h}, 24 \mathrm{~h}, 12 \mathrm{~h}$ and $6 \mathrm{~h}, \mathrm{NLR}_{\mathrm{TN}}$ was increased from $0.28 \mathrm{~kg} / \mathrm{m}^{3} \cdot \mathrm{d}$ to $1.28 \mathrm{~kg} / \mathrm{m}^{3} \cdot \mathrm{d}$ and the anammox activity was further improved with the shorting of HRT.
Changes in stoichiometry under different HRT conditions: Fig. 4 shows the changes of $\Delta \mathrm{NO}_{2}^{-}-\mathrm{N} / \mathrm{NH}_{4}^{+} \mathrm{N}$ and $\Delta \mathrm{NO}_{3}^{-}-\mathrm{N} / \mathrm{NH}_{4}^{+}-\mathrm{N}$ under different HRT conditions. Table 2 shows the average $\mathrm{NO}_{2}^{-}-\mathrm{N} / \mathrm{NH}_{4}^{+}-\mathrm{N}$ values and $\Delta \mathrm{NO}_{3}^{-}-\mathrm{N} /$ $\mathrm{NH}_{4}^{+}-\mathrm{N}$ values in different phases. Formula (1) shows the chemical reaction equation of anammox, the ratio of $\Delta \mathrm{NO}^{-}$ ${ }_{2}-\mathrm{N} / \Delta \mathrm{NH}_{4}^{+}-\mathrm{N}$ is 1.32 and $\Delta \mathrm{NO}_{3}^{-}-\mathrm{N} / \Delta \mathrm{NH}_{4}^{+}-\mathrm{N}$ is 0.26 . These ratios can determine the basis of the anammox reaction. Fig. 4 shows that the ratio of $\Delta \mathrm{NO}_{2}^{-}-\mathrm{N} / \Delta \mathrm{NH}_{4}^{+}-\mathrm{N}$ fluctuated around 1.32 and $\Delta \mathrm{NO}_{3}^{-}-\mathrm{N} / \Delta \mathrm{NH}_{4}^{+}-\mathrm{N}$ fluctuated around 0.26 , which complied with the chemical reaction stoichiometry of anammox. Kang et al. (2019) concluded that the ratio of $\Delta \mathrm{NO}_{2}^{-} \mathrm{N} / \Delta \mathrm{NH}_{4}^{+}-\mathrm{N}$ was 1.22 and $\Delta \mathrm{NO}_{3}^{-}-\mathrm{N} / \Delta \mathrm{NH}_{4}^{+}-\mathrm{N}$ was 0.22 , and the results of this experiment were similar to Kang et al. (2019).

\section{The Morphology of Anammox Granular Sludge}

Apparent characteristics: Fig. 5 shows the apparent characteristics of anammox granular sludge at the initial phase of inoculation and operation for $159 \mathrm{~d}$. The colour of anammox granular sludge was light red, and the average particle size was small at the initial phase of inoculation; when the reactor was operated for $159 \mathrm{~d}$, the colour of anammox granular sludge turned dark red. Tang et al. (2011) concluded that the contents of heme $\mathrm{C}$ increased with the increase of $\mathrm{NRR}_{\mathrm{TN}}$, which lead to the deepening of colour in a similar result to this experiment. Anammox bacteria exhibit the flocculation effect; under the shearing force of a large rising flow rate, the

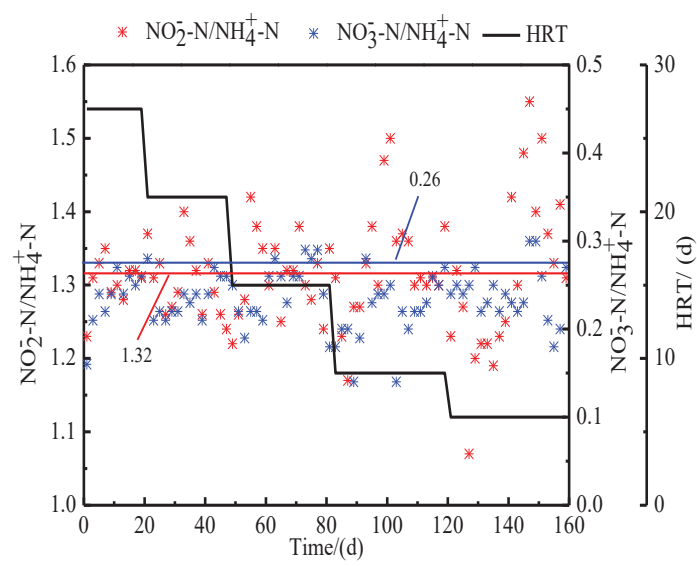

Fig. 4: $\Delta \mathrm{NO}_{2}^{-}-\mathrm{N} / \mathrm{NH}_{4}^{+} \mathrm{N}$ and $\Delta \mathrm{NO}_{3}^{-}-\mathrm{N} / \mathrm{NH}_{4}^{+} \mathrm{N}$ under different $\mathrm{HRT}$ conditions.

Table 2: Average values of $\Delta \mathrm{NO}_{2}^{-}-\mathrm{N} / \mathrm{NH}_{4}^{+} \mathrm{N}$ and $\Delta \mathrm{NO}_{3}^{-}-\mathrm{N} / \mathrm{NH}_{4}^{+} \mathrm{N}$ under different $\mathrm{HRT}$ conditions.

\begin{tabular}{|lllllll|}
\hline $\mathrm{HRT} / \mathrm{h}$ & 27.00 & 20.86 & 15.50 & 8.63 & 6.67 \\
\hline$\Delta \mathrm{NO}_{2}^{-}-\mathrm{N} / \Delta \mathrm{NH}_{4}^{+}-\mathrm{N}$ & 1.30 & 1.31 & 1.31 & 1.33 & 1.31 \\
$\Delta \mathrm{NO}_{3}^{-}-\mathrm{N} / \Delta \mathrm{NH}_{4}^{+}-\mathrm{N}$ & 0.23 & 0.24 & 0.24 & 0.22 & 0.24 \\
\hline
\end{tabular}


cells gather together and are tired, and anammox granular sludge continues to increase (Lin et al. 2019).

Change in particle size distribution: Fig. 6 shows the particle size distribution of the granular sludge at the bottom of the UASB reactor. The particle size distribution of the granular sludge was characterized by the percentage of the total MLSS of the measured sludge in the range of the particle size gradient. In the initial inoculation, the particle size was $0.50-1.00 \mathrm{~mm}$ of granular sludge which accounted for the highest percentage (specific gravity of $27.42 \%$ ), followed by $1.00-1.50 \mathrm{~mm}$ of granular sludge (specific gravity of $25.84 \%$ ), and the percentage of sludge with a particle size less than $0.50 \mathrm{~mm}$ was as high as $13.89 \%$. However, granular sludge with a particle size greater than $3.00 \mathrm{~mm}$ has the lowest proportion with only $1.09 \%$. Shortening HRTs increase the rising flow rate, and granular sludge growth was promoted. Cong et al. (2014) showed that the particle diam- eter was in the range of $0.5-2.0 \mathrm{~mm}$ by adjusting the rising flow rate to $9.0 \mathrm{~m} \cdot \mathrm{h}^{-1}$ in the EGSB reactor, where granular sludge accounted for more than $65 \%$. After $159 \mathrm{~d}$ operating, the particle size of the granular sludge in the reactor showed an increasing trend. Granular sludge with a particle size larger than $1.5 \mathrm{~mm}$ accounted for $62.32 \%$, with the particle size of 1.50-2.00 mm accounting for the highest proportion of the test $(27.53 \%)$. The specific gravity of $2.00-2.50 \mathrm{~mm}$ was $18.47 \%$, the proportion of $2.50-3.00 \mathrm{~mm}$ was $11.03 \%$, particle size greater than $3 \mathrm{~mm}$ increased by 4.1 percentage points from the initial inoculation, and the specific gravity of granular sludge with the particle size of 1.00-1.5 mm was $14.04 \%$. The specific gravity of granular sludge with particle size less than $0.50 \mathrm{~mm}$ was only $8 \%$, which was 5.89 percentage points lower than the initial inoculation. An et al. (2013) obtained the physical properties of anammox granules with different sizes. $1.0 \sim 1.5 \mathrm{~mm}$ granular sludge

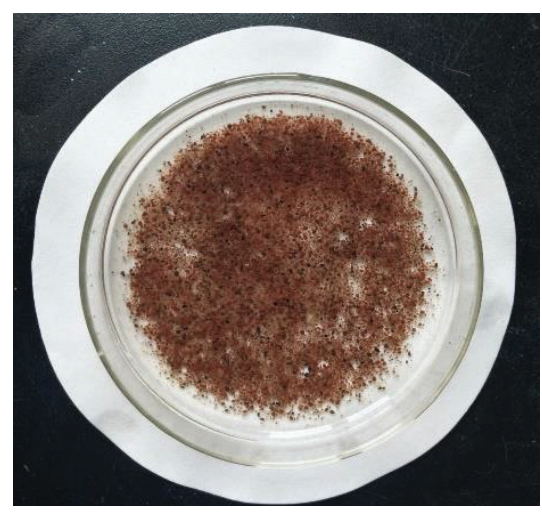

(a)

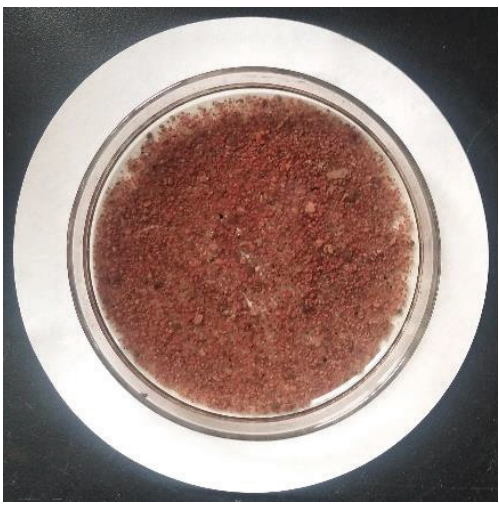

(b)

Fig. 5: The variation of anammox granular sludge in (a) $0 \mathrm{~d}$ and (b) $159 \mathrm{~d}$.

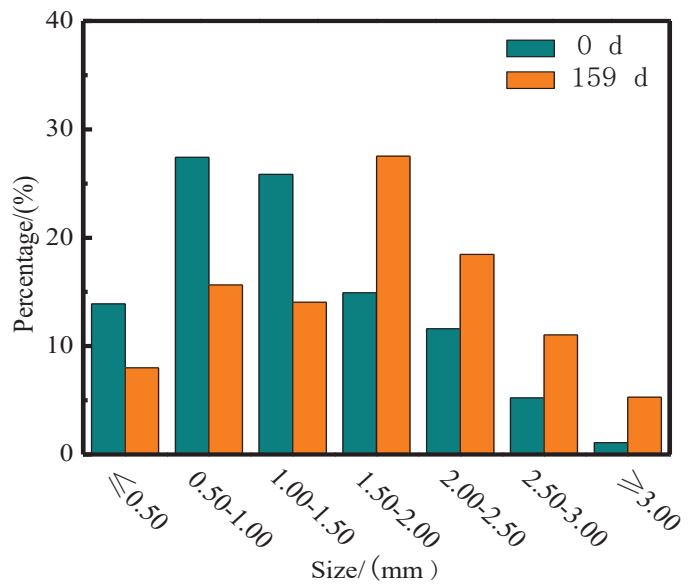

Fig. 6: The changes in the size distribution of anammox granules at different phases. 
has the highest activity, and larger granular sludge was more resistant to temperature and nitrogen load shock. However, larger particles also showed larger gas passages and internal voids, reducing the stability of the granular sludge. It can be seen that on the $159 \mathrm{~d}$ of the reactor operation, the particle size of the anammox granular sludge gradually changed from small to large. In this experiment, the anammox granular sludge was mainly concentrated in the range of less than 1.00 $\mathrm{mm}$, and the domesticated granular sludge was obtained. The diameter was concentrated in the range of more than 1.50 $\mathrm{mm}$, which was essentially in the particle size range with the highest activity of anammox granular sludge.

FT-IR analysis of granular sludge: Secretions during the cell grew, the shedding of the cell surface, cell lysis and the adsorption of substances from the external environment can carry a large number of functional groups on the surface of the sludge. There are currently many studies on the compositions of EPS and the characteristics of anammox granular sludge (Lotti et al. 2019, Feng et al. 2019, Chen et al. 2016, Fang et al. 2018), but few scholars have reported on the surface functional group properties of anammox granular sludge.

Fig. 7 shows that the characteristics of the functional groups' composition of anammox granular sludge by infrared spectroscopy. In the beginning, the vibration near $3393 \mathrm{~cm}^{-1}$ mainly represented $\mathrm{O}-\mathrm{H}$ stretching vibration and represented the alkane organic matter and $\mathrm{C}-\mathrm{H}$ in the polysaccharide molecule near $2930 \mathrm{~cm}^{-1}$. O-H stretching vibration in the carboxyl functional group was represented at around $2525 \mathrm{~cm}^{-1}$, $\mathrm{C}=\mathrm{O}$ stretching vibration in protein amide $\mathrm{I}$ was represented at $1600-1700 \mathrm{~cm}^{-1}$, and the peak near $1040 \mathrm{~cm}^{-1}$ represented C-O-C stretching of polysaccharide or similar polysaccharide substance vibration. In addition, an obvious absorption peak was also found near the wavelengths of $880 \mathrm{~cm}^{-1}, 710 \mathrm{~cm}^{-1}$, and $600-900 \mathrm{~cm}^{-1}$ which were the fingerprint areas (Yan et al. 2015, Badireddy et al. 2010). Infrared spectroscopy revealed sugar and protein in the surface of anammox granular sludge. As the reaction progressed, a more obvious peak appeared near $3290 \mathrm{~cm}^{-1}$, which was mainly caused by N-H stretching vibration in amides. The peak intensities of $2930 \mathrm{~cm}^{-1}$ and $1788 \mathrm{~cm}^{-1}$ increased, indicating C-H stretching in the alkane organic matter and polysaccharide molecules. $\mathrm{C}=\mathrm{O}$ stretching vibration in the vibration and protein amide I were enhanced, and the sugar and protein contents were further enhanced.

\section{Substrates Inhibition of Anammox and Its Kinetic Analysis}

Anammox bacteria used ammonia and nitrite as substrates. At low concentrations, anammox bacteria used the substrates to react. However, at high concentrations, the activity of anammox bacteria is inhibited.

Substrates inhibition kinetics can be described using the Haldane model, which was:

$$
v=\frac{v_{\max }}{1+\frac{K \mathrm{~s}}{S}+\frac{S}{K_{h}}}
$$

Where $v$ is the removal rate of substrates, $\mathrm{mg} /(\mathrm{mg} \cdot \mathrm{d}) ; v_{\max }$ is the maximum conversion rate, $\mathrm{mg} /(\mathrm{mg} \cdot \mathrm{d}) ; S$ is the substrate concentration, $\mathrm{mg} / \mathrm{L} ; \mathrm{k}_{\mathrm{S}}$ is a half-saturation constant, $\mathrm{mg} / \mathrm{L}$; and $K_{\mathrm{h}}$ is the inhibition kinetic constant of Haldane, $\mathrm{mg} / \mathrm{L}$.

Since the Haldane model was a kinetic simulation of a single substrate reaction, for anammox reactions under dual substrates conditions, it was first necessary to control a substrate concentration to examine the effect of another substrate concentration. Firstly, the $\mathrm{NO}_{2}^{-}-\mathrm{N}$ concentration was controlled to $100 \mathrm{mg} / \mathrm{L}$, and the effect of $\mathrm{NH}_{4}^{+}-\mathrm{N}$ concentration on anammox activity was studied. Table 3 shows that in the range of experimental concentration with the increase of $\mathrm{NH}_{4}^{+}-\mathrm{N}$ concentration, the degradation rate increased at first and then decreased.

Fig. 8 shows the kinetic characteristics of ammonium nitrogen inhibition. The correlation kinetic data of the measured ammonium was fitted to the Haldane model using Origin 8.0 software. The correlation coefficient $\left(R^{2}\right)$ of the fitted curve was 0.9912 , and the correlation was good. When the $\mathrm{NH}_{4}^{+} \mathrm{N}$ concentration reached $303.03 \mathrm{mg} / \mathrm{L}$, the anammox

Table 3: Effect of $\mathrm{NH}_{4}^{+}-\mathrm{N}$ concentrations on Anammox bacterial activity.

\begin{tabular}{|llll|}
\hline $\mathrm{NO}_{2}^{-}-\mathrm{N}$ concentration $(\mathrm{mg} / \mathrm{L})$ & $\mathrm{NH}_{4}^{+}-\mathrm{N}$ concentration $(\mathrm{mg} / \mathrm{L})$ & $\begin{array}{l}\mathrm{The} \text { degradation rate of } \mathrm{NH}_{4}^{+}-\mathrm{N} \\
{[\mathrm{mg} /(\mathrm{mg} . \mathrm{d})]}\end{array}$ & $\begin{array}{l}\text { The degradation of } \mathrm{NO}_{2}^{-}-\mathrm{N} \\
{[\mathrm{mg} /(\mathrm{mg} . \mathrm{d})]}\end{array}$ \\
\hline 100 & 70 & 0.075 & 0.130 \\
100 & 100 & 0.105 & 0.098 \\
100 & 200 & 0.126 & 0.109 \\
100 & 320 & 0.139 & 0.113 \\
100 & 500 & 0.127 & 0.108 \\
100 & 600 & 0.121 & 0.084 \\
\hline
\end{tabular}




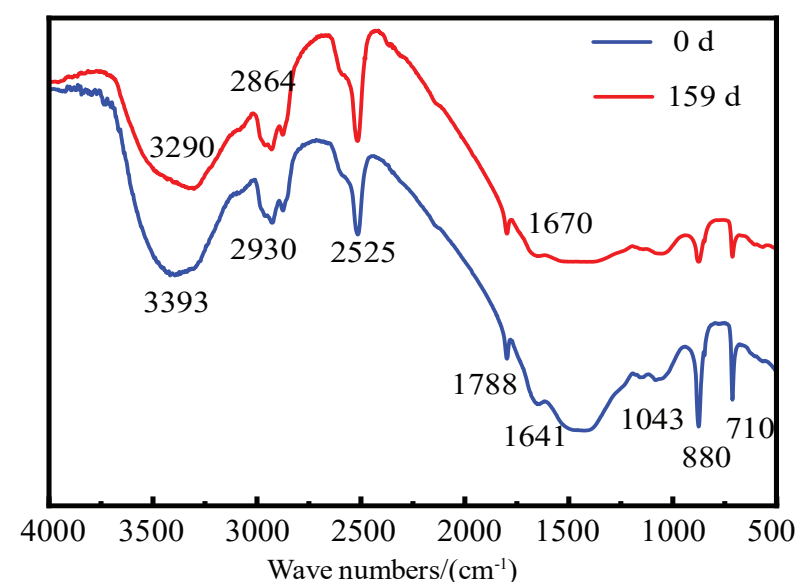

Fig. 7: The FT-IR spectra of granular sludge.

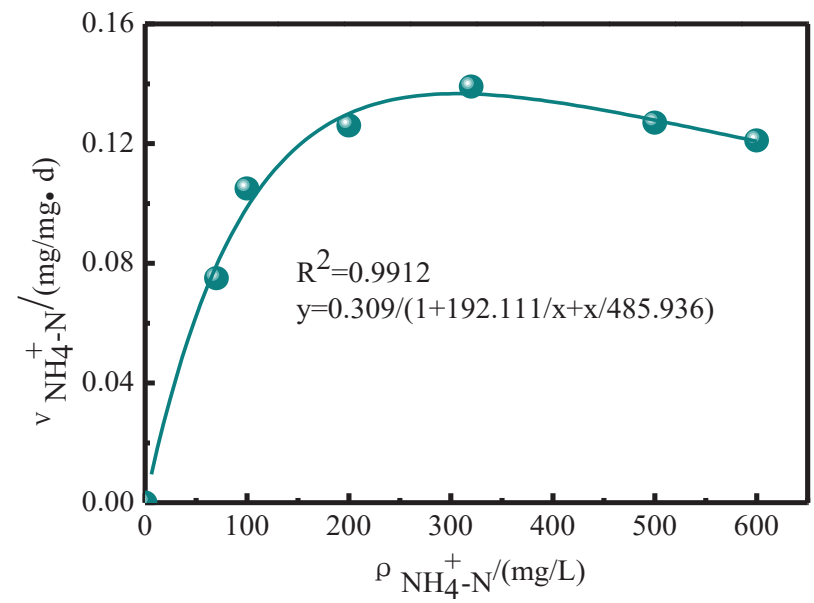

Fig. 8: Inhibition kinetic characteristics of $\mathrm{NH}_{4}^{+}-\mathrm{N}$ concentration on anammox granular sludge.

activity was the highest, and the $\mathrm{NH}_{4}^{+} \mathrm{N}$ degradation rate was $0.137 \mathrm{mg} /(\mathrm{mg} . \mathrm{d})$. When the $\mathrm{NH}_{4}^{+}-\mathrm{N}$ concentration was 600 $\mathrm{mg} / \mathrm{L}$, the degradation rate of $\mathrm{NH}_{4}^{+} \mathrm{N}$ decreased to 0.121 $\mathrm{mg} /(\mathrm{mg} . \mathrm{d})$, whereas the maximum reaction rate $\left(v_{\max }\right)$ was $0.309 \mathrm{mg} /(\mathrm{mg} . \mathrm{d})$, the half-saturation constant (Ks) was $192.111 \mathrm{mg} / \mathrm{L}$, and the inhibition kinetic constant was $485.936 \mathrm{mg} / \mathrm{L}$.

$\mathrm{NH}_{4}^{+}-\mathrm{N}$ concentration was controlled to be $70 \mathrm{mg} / \mathrm{L}$, and the effect of $\mathrm{NO}_{2}^{-}-\mathrm{N}$ concentration on anammox activity was studied. Table 3 shows that in the range of experimental concentration with the increase of $\mathrm{NO}_{2}^{-}-\mathrm{N}$ concentration, the degradation rate increased at first and then decreased.

Fig. 9 shows the kinetic characteristics of nitrite inhibition. The correlation inhibition kinetic data of the measured nitrite was fitted to the Haldane model using Origin 8.0 software. The correlation curve $\left(\mathrm{R}^{2}\right)$ of the fitted curve was 0.9949 and the result was high. When the concentration of $\mathrm{NO}_{2}^{-}-\mathrm{N}$ reached $169.70 \mathrm{mg} / \mathrm{L}$, anammox activity was highest, and the degradation rate of $\mathrm{NO}_{2}^{-}-\mathrm{N}$ was $0.115 \mathrm{mg} /(\mathrm{mg} . \mathrm{d})$. When the concentration of $\mathrm{NO}_{2}^{-}-\mathrm{N}$ reached $400 \mathrm{mg} / \mathrm{L}$, the degradation rate of $\mathrm{NO}_{2}^{-}-\mathrm{N}$ decreased to $0.068 \mathrm{mg} /(\mathrm{mg} . \mathrm{d})$. The maximum reaction rate $\left(v_{\max }\right)$ was $0.737 \mathrm{mg} /(\mathrm{mg} . \mathrm{d})$, the half-saturation constant $(\mathrm{Ks})$ was $456.739 \mathrm{mg} / \mathrm{L}$, and the inhibition kinetic constant was $61.968 \mathrm{mg} / \mathrm{L}$.

Results showed that when the inhibitor was ammonium, the maximum inhibitory concentration was $303.03 \mathrm{mg} / \mathrm{L}$, the $\mathrm{NH}_{4}^{+}-\mathrm{N}$ degradation rate was $0.137 \mathrm{mg} /(\mathrm{mg} . \mathrm{d})$, and the maximum reaction rate was $0.309 \mathrm{mg} /(\mathrm{mg} \cdot \mathrm{d})$. When nitrite was an inhibitor, the maximum inhibitory concentration was $169.70 \mathrm{mg} / \mathrm{L}$, the degradation rate of $\mathrm{NO}_{2}^{-}-\mathrm{N}$ was $0.115 \mathrm{mg} /$ 
Table 4: Effect of $\mathrm{NO}_{2}^{-}-\mathrm{N}$ concentrations on Anammox bacteria activity.

\begin{tabular}{|llll|}
\hline $\mathrm{NH}_{4}^{+}-\mathrm{N}$ concentration $(\mathrm{mg} / \mathrm{L})$ & $\mathrm{NO}_{2}^{-}-\mathrm{N}$ concentration $(\mathrm{mg} / \mathrm{L})$ & $\begin{array}{l}\mathrm{The} \text { degradation rate of } \mathrm{NH}_{4}^{+}-\mathrm{N} \\
{[\mathrm{mg} /(\mathrm{mg} . \mathrm{d})]}\end{array}$ & $\begin{array}{l}\text { The degradation of } \mathrm{NO}_{2}^{-}-\mathrm{N} \\
{[\mathrm{mg} /(\mathrm{mg} . \mathrm{d})]}\end{array}$ \\
\hline 70 & 80 & 0.086 & 0.092 \\
70 & 110 & 0.958 & 0.104 \\
70 & 210 & 0.114 & 0.111 \\
70 & 270 & 0.097 & 0.108 \\
70 & 300 & 0.088 & 0.101 \\
70 & 400 & 0.068 & 0.083 \\
\hline
\end{tabular}

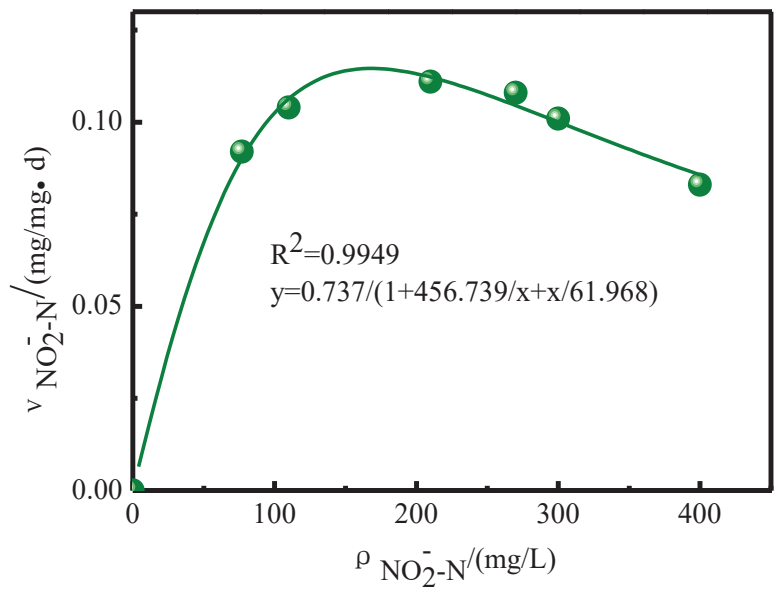

Fig. 9: Inhibition kinetic characteristics of $\mathrm{NO}_{2}^{-}-\mathrm{N}$ concentration on anammox granular sludge.

(mg.d), and the maximum reaction rate was $0.737 \mathrm{mg} /(\mathrm{mg} \cdot \mathrm{d})$. In contrast, the inhibitory effect of nitrate was more significant in both substrates. Similarly, Li et al. (2016) showed that the removal rate of ammonia and nitrite by inhibition kinetic sequencing batch tests increased at first and then decreased. The ammonia nitrogen concentration was 295.62 $\mathrm{mg} / \mathrm{L}$, anammox activity was the highest, and the ammonia nitrogen degradation rate was $0.1540 \mathrm{mg} /(\mathrm{mg} \cdot \mathrm{d})$. The nitrite degradation rate was $0.1649 \mathrm{mg} /(\mathrm{mg} \cdot \mathrm{d})$ at the concentration of $151.10 \mathrm{mg} / \mathrm{L}$, and anammox activity was the highest.

\section{CONCLUSIONS}

(1) Anammox granular sludge that was used UASB as the reactor by shorting hydraulic retention time (HRT shortened from $27 \mathrm{~h}$ to $6.67 \mathrm{~h}$ ) was enriched. After 159 $\mathrm{d}$ of operation, the $\mathrm{NRE}_{\mathrm{NH}+4-\mathrm{N}}$ and $\mathrm{NRE}_{\mathrm{NO}_{2}^{-} \mathrm{N}}$ reached more than $95 \%$, the $\mathrm{NRE}_{\mathrm{TN}}$ was $81.53 \%$, and the $\mathrm{NRR}_{\mathrm{TN}}$ reached $1.33 \mathrm{~kg} /\left(\mathrm{m}^{3} . \mathrm{d}\right)$.

(2) In the initial phase of inoculation, the percentage of granular sludge with the particle size of $0.50-1.00 \mathrm{~mm}$ was the highest (specific gravity was $27.42 \%$ ), and the proportion of granular sludge with particle size greater than $3.00 \mathrm{~mm}$ was the lowest, only $1.09 \%$. At $159 \mathrm{~d}$, the average particle size of the granular sludge in the reactor showed an increasing trend, with the highest percentage of $1.50-2.00 \mathrm{~mm}$ (specific gravity $27.73 \%$ ), and the particle size larger than $3 \mathrm{~mm}$ accounted for $5.29 \%$, which was 4.1 percentage points higher than the initial inoculation.

(3) Analysing the anammox granular sludge via the Fourier transform infrared spectroscopy revealed that mainly sugar and protein were on the surface of anammox granular sludge. After $159 \mathrm{~d}$ of reactor operation, the sugar and protein content further increased.

(4) By inhibition of the kinetic sequencing batch test, the maximum reaction rate was $0.309 \mathrm{mg} /(\mathrm{mg} \cdot \mathrm{d})$, the half-saturation constant $(K s)$ was $192.111 \mathrm{mg} / \mathrm{L}$, and the inhibition kinetic constant was $485.936 \mathrm{mg} / \mathrm{L}$. The nitrite maximum reaction rate was $0.737 \mathrm{mg} /(\mathrm{mg} \cdot \mathrm{d})$, the semi-saturation constant $(K \mathrm{~s})$ was $456.739 \mathrm{mg} / \mathrm{L}$, and the inhibition kinetic constant was $61.968 \mathrm{mg} / \mathrm{L}$. In contrast, the anammox bacteria in the two substrates were more significantly inhibited by nitrate. 


\section{ACKNOWLEDGEMENTS}

This work was financially supported by Hebei Provincial innovation funding project for graduate students (CXZZSS2019071), Hebei Provincial Natural Science Fund Project (E2016402017), Project of Young Top Talents Program in Universities and Colleges of Hebei Province (BJ2019029) and Handan Science and Technology Research and Development Plan (1623209044).

\section{REFERENCES}

APHA 1998. Standard Methods for the Examination of Water and Wastewater. 20th Edn., Edited by American Public Health Association, Washington, DC.

An, P., Xu, X.C., Yang, F.L. and Li, Z.Y. 2013. Comparison of the characteristics of anammox granules of different sizes. Biotechnology and Bioprocess Engineering, 18(3): 446-454.

Badireddy, A.R., Chellam, S., Gassman, P.L., Engelhard, M.H., Lea, A.S. and Rosso, K.M. 2010. Role of extracellular polymeric substances in bioflocculation of activated sludge microorganisms under glucose-controlled conditions. Water Research, 44: 4505-4516.

Chen, T.T., Zheng, P., Shen, L.D., Ding, S. and Mahmood, Q. 2011. Kinetic characteristics and microbial community of Anammox-EGSB reactor. Journal of Hazardous Materials, 190(1-3): 28-35.

Cong, Y., Huang, X. L., Wand, X.L. and Gao, D.W. 2014. Faster formation of anammox granular sludge. Ciesc Journal, 65(2): 664-671.

Cao, Y.S., Van Loosdrecht, M.C.M. and Daiggerr, G.T. 2017. Mainstream partial nitritation - anammox in municipal wastewater treatment: status, bottlenecks, and further studies. Applied Microbiology and Biotechnology, 101(4): 1365-1383.

Chen, H., Hu, H.Y., Chen, Q.Q., Shi, M.L. and Jin, R.C. 2016. Successful start-up of the anammox process: Influence of the seeding strategy on performance and granule properties. Bioresource Technology, 211: 594-602.

Feng, C.J., Lotti, T., Lin, Y.M. and Malpei, F. 2019. Extracellular polymeric substances extraction and recovery from anammox granules: Evaluation of methods and protocol development. Chemical Engineering Journal, 374: 112-122.

Fang, F., Yang, M.M., Wang, H., Yan, P., Chen, Y.P. and Guo,J.S. 2018. Effect of high salinity in wastewater on surface properties of anammox granular sludge. Chemosphere, 210: 366-375.

Kang, D., Yu, T., Xu, D.D., Zeng, Z., Ding, Q., Zhang, M., Shan, S.D., Zhang, W.D. and Zheng, P. 2019. The anammox process at typical feast-famine states: Reactor performance, sludge activity and microbial community. Chemical Engineering Journal, 370(15): 110-119.
Kang, D., Xu, D.D., Yu, T., Feng, C.D., Li, Y.Y., Zhang, M. and Zheng, P. 2019. Texture of anammox sludge bed: Composition feature, visual characterization and formation mechanism. Water Research, 154(1): 180-188.

Li, Y., Li, J., Cai, H., Chen, G., Hou A.Y., Hu, X., Bian, W., Guo, R.F. and Liu, Y.F. 2016. Nitrogen removal and inhibition kinetics of ANAMMOX reactor fed with the mature landfill leachate. China Environmental Science, 36(5): 1409-1416.

Laguna, A., Ouattara, A., Gonzalez, R.O., Baron, O., Fama, R., Mamouni, E., Guiot, S., Monroy, O. and Macarie, H. 1999. A simple and low cost technique for determining the granulometry of upflow anaerobic sludge blanket reactor sludge. Water Science Technology, 40(8): 1-8.

Lin, Q.J, Kang, D., Zhang, M., Yu, T., Xu, D.D., Zeng, Z. and Zheng, P. 2019. The performance of anammox reactor during start-up: Enzymes tell the story. Process Safety and Environmental Protection, 121: 247-253.

Lotti, T., Carretti, E., Berti, D., Martina, M.R., Lubello, C. and Malpei, F. 2019. Extraction, recovery and characterization of structural extracellular polymeric substances from anammox granular sludge. Journal of Environmental Management, 236: 649-656.

Lin, X.M. and Wang, Y.Y. 2017. Microstructure of anammox granules and mechanisms endowing their intensity revealed by microscopic inspection and rheometry. Water Research, 120(1): 22-31.

Mulder, A., Van De Graaf, A.A., Robertson, L.A. and Kuenen, J.G. 1995. Anaerobic ammonium oxidation discovered in a denitrifying fluidized bed reactor. FEMS Microbiol. Ecol, 16(3): 177-183.

Strous, M., Heijnen, J. J., Kuenen, J. G. and Jetten, M. S. M. 1998. The sequencing batch reactor as a powerful tool for the study of slowly growing anaerobic ammonium - oxidizing microorganisms. Applied Microbiology and Biotechnology, 50: 589-596.

Tang, C.J., Duan, C.S., Yu, C., Song, Y.X., Chai, L.Y., Xiao, R.Y., Wei, Z.S. and Min, X.B. 2017. Removal of nitrogen from wastewaters by anaerobic ammonium oxidation (ANAMMOX) using granules in upflow reactors. Environmental Chemistry Letters, 15: 311-328.

Tang, C.J., Zheng, P. and Wang, C.H. 2011. Performance of high-loaded ANAMMOX UASB reactors containing granular sludge. Water Research, 45: 135-144.

Van de Graaf, A.A., de Bruijn, P., Robertson, L.A., Jetten, M.S.M. and Kuenen, J.G. 1996. Autotrophic growth of anaerobic ammonium-oxidizing microorganisms in a fluidized bed reactor. Microbiology, 142(8): 2187-2196.

Yan, L.L., Liu, Y., Wen, Y., Ren, Y., Hao, G.X. and Zhang, Y. 2015. Role and significance of extracellular polymeric substances from granular sludge for simultaneous removal of organic matter and ammonia nitrogen. Bioresource Technology, 179: 460-466.

Yu, Y.C., Tao, Y. and Gao, D.W. 2014. Effects of HRT and nitrite/ammonia ratio on anammox discovered in a sequencing batch biofilm reactor. RSC Advances, 4: 54798-54804. 